\title{
Representation and Agency of Aging Superheroes in Popular Culture and Contemporary Society
}

\author{
Kateřina Valentová
}

Citation: Valentová, K.

Representation and Agency of Aging Superheroes in Popular Culture and Contemporary Society. Societies 2021, 11, 18. https://doi.org/10.3390/soc 11010018

Academic Editors: Lucie Vidovićová and Ieva Stončikaitè

Received: 22 February 2021

Accepted: 4 March 2021

Published: 8 March 2021

Publisher's Note: MDPI stays neutral with regard to jurisdictional claims in published maps and institutional affiliations.

Department of English and Linguistics, Faculty of Arts, University of Lleida, 25003 Lleida, Spain; katerina.valentova@udl.cat

\begin{abstract}
The figure of the superhero has always been regarded as an iconic representative of American society. Since the birth of the first superhero, it has been shaped by the most important historical, political, and social events, which were echoed in different comic issues. In principle, in the superhero genre, there has never been a place for aging superheroes, for they stand as a symbol of power and protection for the nation. Indeed, their mythical portrayal of young and strong broad-chested men with superpowers cannot be shattered showing them fragile or disabled. The aim of this article is to delve into the complex paradigm of the passage of time in comics and to analyze one of the most famous superheroes of all times, Superman, in terms of his archetypical representation across time. From the perspective of cultural and literary gerontology, the different issues of Action Comics will be examined, as well as an alternative graphic novel Kingdom Come (2008) by Mark Waid and Alex Ross, where Superman appears as an aged man. Although it breaks the standards of the genre, in the end it does not succeed to challenge the many stereotypes embedded in society in regard to aging, associated with physical, cognitive, and emotional decline. Furthermore, this article will show how a symbolic use of the monomythical representation of a superhero may penetrate into other cultural expressions to instill a more positive and realistic portrayal of aging.
\end{abstract}

Keywords: cultural and literary gerontology; aging and society; agism; popular culture and comics; DC superheroes

\section{Introduction}

In ancient mythology, the term hero used to represent a being born from a God or a Goddess and a human, placing them between these two: a demigod, such as Achilles or Hercules. These demigods were mortal and living among the mortals. After death, their last journey to the underworld was a psychological and aesthetical mean to overcome their own mortality:

The journey to [ ... ] the underworld is the ultimate experience for the epic hero, representing the imaginative limits of human hope. The tenacity and power of the myth successful confrontation with the world of the dead, and the concept of rebirth and resurrection it implies, demonstrate the almost obsessive need for human beings of all cultures to come to grips with their own mortality by opposing it, psychologically and aesthetically, with stories of its being overcome [1] (pp. 29-30).

Later on, the term hero was used to refer to people who were made immortal symbolically in epic poems, which narrated their incredible deeds in life. Moreover, as it was believed that their souls eternally dwelled underground, they were offered sacrifices to praise their glory as if they were Gods. Yet, these rites were still different from the ones to Gods, as they were performed on lower altars, the sacrificed animals were killed facing the ground, in the direction of their underworld, not divine, home [2].

In the comic genre, many scholars have interpreted American superheroes from comic books as modern Gods and Goddesses, mainly from Greek and Norse mythology [3]. 
Although they are considered beings with special powers, they do not possess the gift of immortality as Greek Gods did. Superman, for instance, is strong and made of steel, but has a well-known weakness: the kryptonite. Similarly, Achilles is brave and invincible except for his heel. Therefore, the comic superhero corresponds to a Greek demigod, to the hero in the original meaning of the word. Yet, as the term has been corrupted and now denotes whoever whose deeds are somehow remarkable (not necessarily because of extraordinary or supernatural powers), the prefix super- is needed in order to place them on the same level with demigods, "on the edge of two worlds: the divine and the human" [4] (p. 201). For these reasons, it can be assumed that the gift of immortality has always been exclusively in possession of Gods, albeit yearned for by humans since the world's origins, because it was the only difference which separated them from the Divine. The American superhero has become a symbol of strength and power and for this reason, it may seem highly improbable to find any who challenges the portrayal of this archetype and is depicted as an aged or aging man. However, if this happen, as is in the cases discussed in this paper, it is of extreme relevance to examine how he is represented and what is his agency in the story, for superhero comics are very popular and have the capacity to reach a broad and diverse readership. Moreover, superhero genre not only reflects society's mind-set, but it can also be influential in challenging cultural stereotypes in regard to aging.

\section{Aging in Comics}

During the history of American comic art, very few comics have introduced older characters. Due to commercial need of continuity of comic series with established stock characters, these can never grow old. If this were not so, no comic saga could exist longer than the life expectancy of a particular character. In the short history of comics, it was not until 1918 that the comic author Frank King introduced characters who aged over time in his comic strips Gasoline Alley (1918-1969). The protagonist, an unmarried man named Walt, very keen on car engines, finds an abandoned baby and decides to adopt it. From that moment on, the nature of this series changes and becomes a family saga of daily life of this newly composed family. According to Santiago García, this comic represents a giant leap in comic history:

King seems to capture the passage of time and, in fact, if there is something distinctive about Gasoline Alley, it is the fact that time really passes by. The characters grow older, like real human beings. Skeezix [the adopted boy] will potentially grow, go to war, get married and have his own children, whereas Walt [the foster father] will also get married and have biological children with his wife [5] (p. 75).

With this family drama, King introduced a real time continuity into comic art, which captures the physiological growth of the protagonist up to old age. For its long-run duration, it is also of great relevance in terms of mirroring a century of social changes in American society. After this important milestone, it is not until the sixties that writers raise awareness in regard to the paradigm of physical aging in comics. Hand in hand with the tendency of adding more realism to the fictional comic world, it is then that artists start to reflect on the ways of how to introduce the dimension of time in their works. For instance, conscious of the relevant contribution of King in comic art, Chris Ware edited the saga under the name of Walt and Skeezix (2005), and admitted a great influence of the author on his oeuvre.

On the other hand, a study published by Heather Hanlon, Judy Farnworth and Judy Murray in 1997, analyzed 20 years (1972-1992) of history of comic strips where older characters appear, with a special emphasis on their societal roles. The results showed that the elderly were underrepresented in American comic strips (women more than men), and their roles were rather negative and stereotyped (men were depicted more frequently in negative roles than women, but the overall numbers pointed to negative portrayals of the older generation in general). Therefore, the final conclusion of the scholars was that "this 
form of communication supports ageism and has the potential to promote stereotypes of ageing" [6] (pp. 302-303).

Fortunately, this tendency towards agism in comics has changed over the years. In fact, in the first decades of the 21st century, there is an important number of graphic novels, where the old characters are depicted if not in a positive light, at least in a realistic way, as a heterogenous group, and given necessary visibility. Among these works can be found titles such as Tangles (2012) by Sarah Leavitt, Can't We Talk about Something More Pleasant? (2014) by Roz Chast, Special Exits (2014) by Joyce Farmer, or Displacement (2015) by Lucy Knisley, to name the most relevant ones. Nevertheless, it is also important to bear in mind that there is an important difference between graphic novels and comics. Whereas the former has acquired the status of high literature, the latter still belongs to popular culture which is stigmatized for disseminating cultural stereotypes.

On the American comic scene belonging to pop culture, a dominant position is hold by the genre of superheroes as "the hero with superhuman powers appeared just as modern American comic book publishing was in its infancy and quickly dominated the output of the nascent industry during the late 1930s and early 1940s" [7] (p. 362). In fact, since its first mention in 1917, the term superhero was used to refer to a public figure of great accomplishments. The American superhero was born as a result of "decades of pulp, film and penny dreadful predecessors" [3] (p. 17), and coincides with the times of the Great Depression when this kind of savior was needed. A superhero soon becomes an inseparable part of American culture, a kind of symbol. In June 1938, Jerry Siegel's and Joe Shuster's Superman made his debut in Action Comics, lifting a car above his head on the front page of the first issue. It was a complete success and the 200.000 copies were soon sold out [5]. The first authors of superhero comics belonged to the working class as well as their readership. According to Brooker, "these earliest examples express a deep and underlying distrust of capitalism and a strong desire to change society for the better via a seemingly simplistic mission to right wrongs and fight crime" [7] (p. 362).

\section{A Brief Historical Overview of the Most Famous American Superhero, Superman}

Superheroes' origins are embedded in mythology, as stated before. However, it is not only because they deal with topics such as good and evil, structure and entropy, or friend and enemy, but because "superhero stories also carry the dominant moral values of a culture", and "offer ideological representations of gender, race, sexuality and nation" [8] (p. 2). In a similar light, Joseph Campbell claims that the hero's journey as a type of a monomyth is very much needed in many cultures [4]. Therefore, the first Superman fights the ills of capitalism in the midst of the Great Depression, and serves as a direct response to the morality, as well as a voice of the oppressed working class in the late American 1930s.

During the World War II, and specifically after the Japanese attack on Pearl Harbor in 1941, Superman mirrors American positioning within the conflict, and adopts the paper of a protector and a patriotic symbol. "As war propaganda, many comics promoted this mentality to encourage the loyalty and determination of American people to their country and the war effort" [9] (p. 12). Superman's fights no longer involve solely American citizens, but he fights against foreign enemies such as Hitler and the Nazis (Figure 1), the Japanese, and even Joseph Stalin. Within the Action Comics, he also adopts the role of a spokesman, encouraging his readership to contribute to supporting the war heroes and the cause.

This time coincides with the period of the First Heroic Age, generally known as the Golden Age of the superhero genre, for there was a great boom of superheroes published by almost every known publisher (Among these, Brooker names The Shield, The Wizard, Hangman, Black Hood, The Comet by ML J Magazines, or Doll Man, Quicksilver, Uncle Sam and Human Bomb by Quality Comic Group, etc., see [7] (p. 363). Those superheroes that have endured until nowadays are considered the archetypes of the genre: Superman, Batman, Wonder Woman, Green Lantern, Flash, or Hawkman by DC, and Captain America, Sub-Mariner, or Human Torch by Marvel, to name the most relevant ones [7]. 


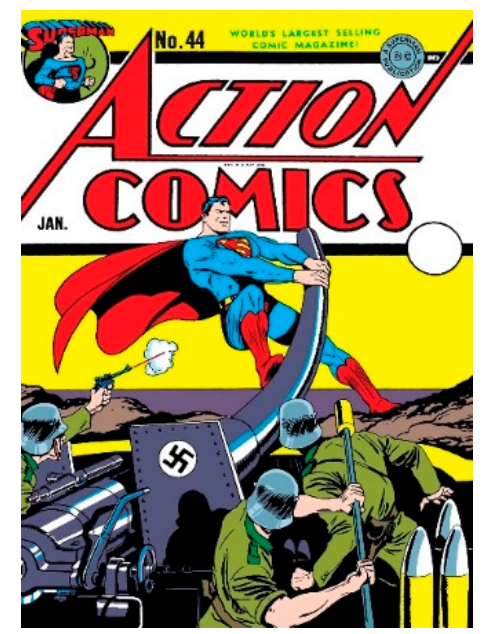

Figure 1. Action Comics \#44, “The Caveman Criminal” (January 1942) [10].

In the early 1950s, "American's life mostly revolved around two things: the nuclear family and work. There was also an emphasis on obeying the law and social norms. Alternatively, because of the creation of the atomic bomb and the start of the Cold War with the Soviet Union, this era saw paranoia like no other under the constant threat of nuclear warfare and Russian spies" [9] (p. 17). On the other hand, Superman's popularity decreases as it was thought that this kind of comic, constantly showing crime and violence, could possibly have a psychological and corrupting effect on America's youth. A crusade led by Frederic Wertham against these comics caused new stories with Superman to be directed toward an adult audience and for children, there would be an alternative version of Superboy [7]. In the Silver Age of comics, the different episodes would become less violent, turning their focus on domestic life (Figure 2). In this period, Superman's girlfriend Lois Lane is announced, making Superman more humanlike and becoming a symbol of comfort after the horrors of WWII. Kryptonite is introduced as Superman's Achilles' Heel, putting more emphasis on his vulnerability. In general terms, there is "a change conducive to the emphasis on his supporting cast, while a greater focus on Superman's personal life and friendships becomes the norm in his narratives [11] (p. 801). This, however, does not meet the trends of the counterculture of the 1960s, and therefore Marvel's superheroes become trendier and more aligned with the role of reflecting American society.

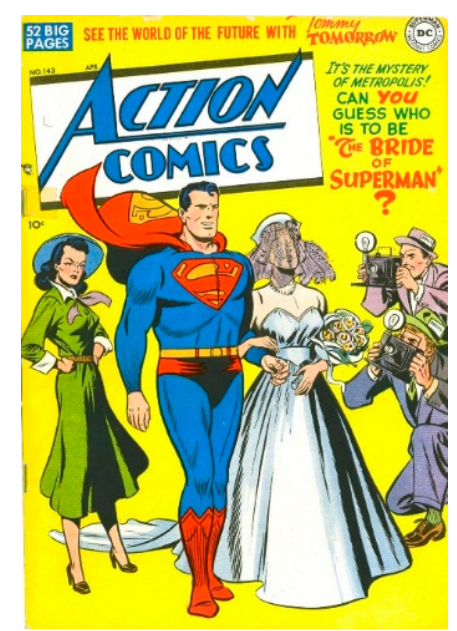

Figure 2. Action Comics \#143, “The Bride of Superman" (April 1950) (In this period, women begin to appear in the different covers of the Action Comics issues, representing the sentimental as well as domestic side of Superman in the 1950s) [10]. 
In the 1970s, Superman undergoes an important change again. Firstly, as technology had progressed in a significant way, the issues from this period point to possibly no need of his services. Superman represents traditional values in a changing world, which were also in crisis. The focus of Superman's narratives in this period of time lies in more socially conscious topics of a morally crippled society, such as racism or drug abuse, and on the other hand, it mirrors the increasing popularity of rock music and fascination with space missions. Moreover, Superman enters into 'high culture' thanks to Andy Warhol's art, and the interest of Umberto Eco and Natalie Chilton in carrying out an important scholarship about his archetypical relevance. The 1980s are still marked by fear of the Soviet menace and Superman is reduced to a weapon of political propaganda of Reagan's times, with a sharp, aggressive, and militaristic character.

Finally, the 1990s are marked by the end of the Cold War and the search for a new American identity. It is also time of the terrorist menace and many superhero comics echo this fear. "The $90 \mathrm{~s}$ was a reflection of $70 \mathrm{~s}$ issues in the sense that it was a decade where both Superman and American Society struggled to find their new identity" [9] (p. 30). On the other hand, Martha and Jonathan Kent, Superman's adoptive parents, take on a more prominent role in the series, but without any further development in regard to their psychological or physiological level, rendering them visible but flat.

\section{Physical Appearance of Superman across Time}

It is curious that even though Superman as a character undergoes different phases of development regarding the plot and focus in the series, he hardly changes physically. In fact, it may seem that in the superhero genre, there is apparently no place for old protagonists, as they would not be able to fulfil the archetypical expectations of what a canonical superhero is supposed to represent. Revising the evolution of the most famous superhero of times, Superman, it is shown that from his very arrival up to the 1990s, the reader is offered an unchanged image of a strong and muscular man, with his stylish velvety black quiff (This physical representation is slightly changed in the representation of Superman by Denis Rodier (September 1993-September 1997) who depicts him with longer curly hair. However, Stuart Immonen goes back to the archetypical hairstyle the readership was used to from previous issues), who actually never grows old, save some exceptions that will be discussed hereunder.

The first physical change of Superman into an aged man can be found in Action Comics \#251, titled "The Oldest Man in Metropolis" (April 1959). The authors introduce a scientist who tries to invent a serum to increase human's life span, and which is tested on Superman. The effects of this serum make him grow old overnight, and his superpowers do not result to work in his elderly body. He is depicted with a walking stick and a long white beard (Figure 3), a typecast portrayal of an old man. However, in this issue, Superman takes advantage of his fragile appearance, which helps him to fight the enemies.

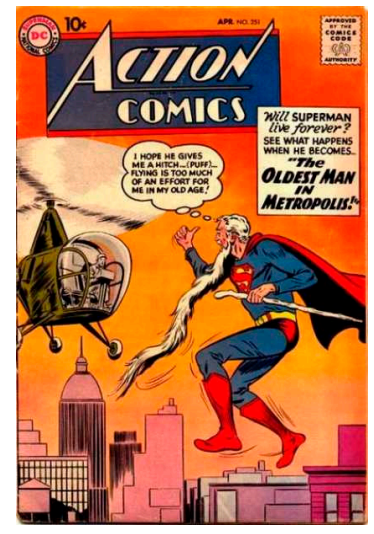

Figure 3. Action Comics \#251, "The Oldest Man in Metropolis" (April 1959) [10]. 
In a similar way, Action Comics \#270 titled “The Old Man of Metropolis!" (November 1960) displays Superman as an old man (Figure 4). In this issue, Superman visits an orphanage and is given an essay where he is described as having grown old, and how the author of that paper, once becoming an adult, would take his place. After an accidental exposition to Kryptonite, he is transported to the future and finds himself as an old man being replaced by the now adult Superwoman. His superpowers are weakened by the age, and he also needs to wear glasses to read. Although it turns to be only a dream, this issue explores an alternative reality with an old Superman, but still perpetuates the portrayal of the elderly as useless and unproductive members of society.

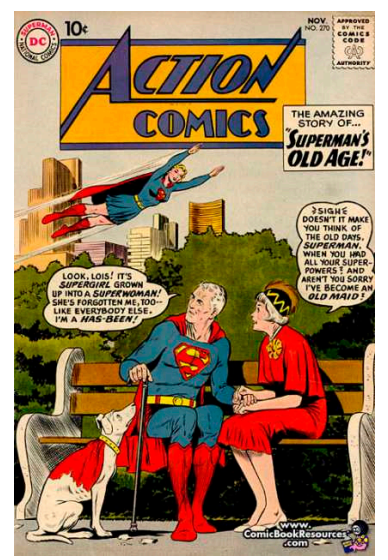

Figure 4. Action Comics \#270, “The Old Man of Metropolis!” (November 1960) [10].

In the Action Comics \#327 titled “The Three Generations of Superman" (August, 1965), The Man of Steel appears as an aged, retired man, together with Jor-El II in the role of his son and successor, and Kal-El II as his grandson (Figure 5). Superman is retired and is portrayed as a physically active agent, taking part in his grandson's adventures, and telling him stories from times before his retirement. Even though Superman is still depicted as a man whose powers are weakened by age whereas the grandson's are full, this issue offers an interesting insight on positive intergenerational relationships, as they both work together in order to fight masked crooks.

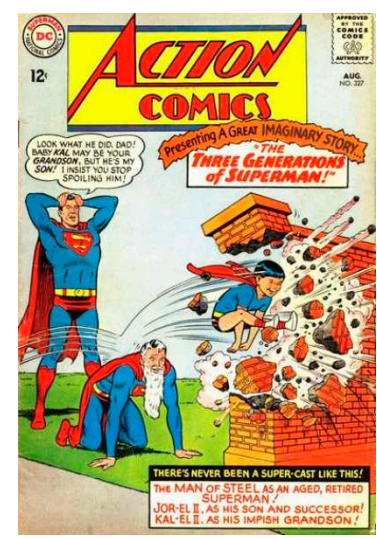

Figure 5. Action Comics \#327, “The Three Generations of Superman” (August 1965) [10].

In the 1970s, there are three consecutive issues which deal with immortality, aging, and death. These issues coincide with the period where Superman enters in crisis due to technological development, which eventually renders him useless. Superman, representing traditional values in a changing world, becomes outdated, and therefore is placed in a distant future where he might find some reasons for his existence. In the Action Comics \#385, titled “The Immortal Superman!” (February 1970), Superman travels to the future 
through a kind of time-bubble, where he is trapped and cannot come back. He starts to age because of a defect in the time-bubble, but his powers are maintained. On the cover, he is portrayed with grey hair, but still muscular and hearty (Figure 6). In a further future, he meets three superheroes who make him immune to his weaknesses, rendering him immortal. Superman is 100,000 years old and doctors state that he became immortal. However, as all his beloved people are dead, it is not a positive message for Superman (The concept of immortality has been broadly discussed in popular culture and literature. The special breed of struldbrugs in Gulliver's Travels (1899) by Jonathan Swift, or the song by Brian May "Who Wants to Live Forever?" in the movie Highlander (1986) transmit a similar message. According to Swift in his novel, eternity brings nothing but enough time to suffer from loneliness and all the ills that old age brings, reproducing one of the commonest stereotypes embedded in our society in relation to senescence. Despite that, immortality has been always yearned for by humans from the world's origins to today's efforts to combat aging in the field of science and transhumanist theories).

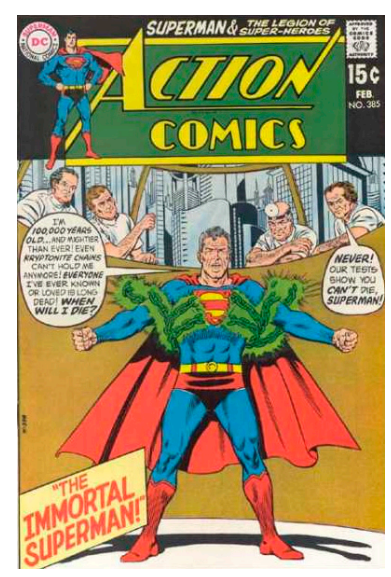

Figure 6. Action Comics \#385, “The Immortal Superman!” (February 1970) [10].

In the Issue \#386 titled “The Home for Old Super-Heroes!” (March 1970), Superman travels even further into the future, and finds himself in an alternative world, in a retirement home with other aged superheroes. The cover depicts aging men in colorful costumes reminiscing about their glorious past as superheroes, and they all share the same story which left them in this situation (Figure 7): "And I was Superman on the planet Earth! But like the rest of you, I've outlived my usefulness! No one wants me around anymore!" Once again, this issue points to the general perception of the elderly as useless and unproductive members of society set apart.

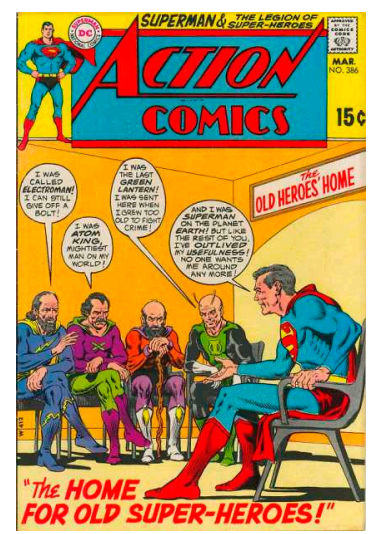

Figure 7. Action Comics \#386, “The Home for Old Super-Heroes!” (March 1970) [10]. 
The following issue, "Even A Superman Dies!” (April 1970), sets the plot in a far future where Superman does not have anything to do but to live in "an eternity of boredom". He is eventually killed by radiation from a small spacecraft and floats inert in the universe. Finally, he is saved by a robotic healer (Figure 8) who brings him back to life: "I saved your life!" "WHAT? Why did you do a fool thing like that? I'm over a million years old... I've outlived everything and everybody I cared about.... I WANTED to die!". For an old Superman, in a future without any friends and any tasks to fulfil, there is no reason to live.

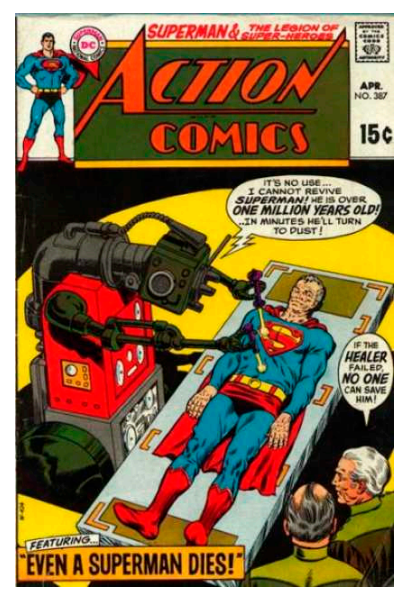

Figure 8. Action Comics \#387, “Even A Superman Dies!” (April 1970) [10].

In Action Comics \#396 titled “The Super-Panhandler of Metropolis!" (January 1971), Superman appears in a wheelchair (Figure 9), almost powerless, and observes how technological development replaced the need for Superman. Similarly, in the following issue, \#397 titled "The Secret of the Wheel-Chair Superman!" (February 1971), Superman, in the condition of a beggar and with fading superpowers, starts to suffer from mental hysteria as a result of not being needed by society (Figure 10). As his existence is rendered useless, he flies away to look for any other possible universe in need of a superhero.

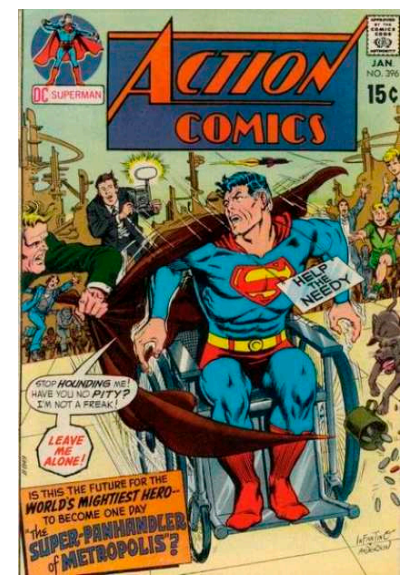

Figure 9. Action Comics \#396, “The Super-Panhandler of Metropolis!” (January 1971) [10].

In a nutshell, what can be found in the different issues of Superman in Action Comics since 1939, is an unchanged portrayal of the Man of Steel, representing the American icon who dwells for the well-being of American citizens. His archetypical representation of a broad-chest muscular man with superpowers is key for the development of different plots throughout history. As Brooker puts it, "Superheroes emerge from this same mythic tradition, but are changed and further mutated by the historical context of their development" [7] (p. 365). Even though Superman has undergone different changes mirroring the key events in American society, he has not evolved physically except for the eight examples 
discussed, where the authors experiment with alternative realities, but doing so, they do nothing but perpetuate a biased portrayal of an aged man with white hair, wearing glasses or being prostrate in a wheelchair, with fading superpowers due to his age and, especially, as an inactive agent, set apart from society because he is no longer productive or needed. This portrayal coincides with the one coined in society that has been challenged these last few decades. This reductionism of the later stage of life to frailty and decay has long been fought against, and new policies have been implemented with the concept of 'active' or 'positive' aging, where old people have been empowered to take an active role in their life and well-being $[12,13]$. This recent tendency on the social level goes far beyond the efforts of science, which, instead, looks for ways to slow down the process of aging.

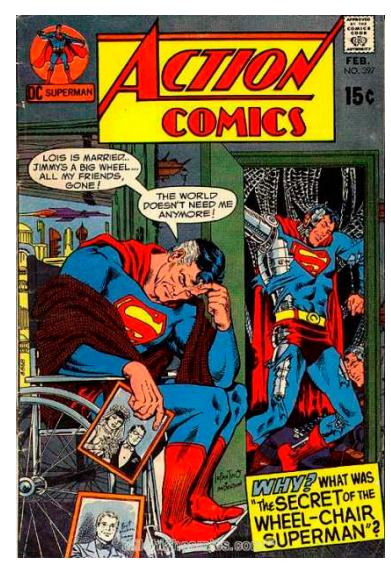

Figure 10. Action Comics \#397, “The Secret of the Wheel-Chair Superman!” (February 1971) [10].

\section{Superhero and Myth}

The fact that Superman never grows old can be explained through the theory of 'mythification of images', attributing to them an iconic value [14]. In the Middle Ages, this theory consisted in allocating symbolic meanings to certain images by clericals in order to embed them in collective consciousness. This was done by capturing the iconic value of certain archetypical images and borrowing elements from the whole logical and iconographical tradition which were, in popular fantasy, associated with specific psychological, moral, or supernatural events. In popular culture, the image of Superman has been gradually mythicized and added to other symbolic heroes such as Hercules, Siegfried, Orlando, Pantagruel, or even Peter Pan. Eco claims that "a positive hero has to embody $[\ldots]$ the power demands which the average citizen nurtures but cannot satisfy" [14] (p. 14). However, according to Neal Curtis, "What they call the American monomyth is a deeply anti-social, if not sociopathic, adaptation of Campbell's classic version of the hero's journey" [8] (p. 3).

Superman is, according to Eco, the best example of such a hero. Although originally from another planet, he lives among ordinary people, but unlike them, he is extremely strong, able to fly and travel in time, cut woods, perforate mountains, has X-ray vision, ultrasensitive hearing, etc. (In regard to all his superpowers, these were added progressively alongside his evolution as a character). Moreover, "he is kind, handsome, modest, and helpful; his life is dedicated to the battle against the forces of evil and the police find him an untiring collaborator" [14] (p. 14). In Greek mythology, Superman would correspond to a demigod (both share an ordinary life with the rest of the citizens), until the moment he is needed; by means of a disguise, he switches his identity from a journalist Clark Kent to an infallible superhero.

Gavaler ascribes one of the possible reasons for the popularity of superhero comics to cognitive psychology. According to several studies, "members of different cultures produce similar stories not because they share a collective unconscious, but because they share similar brains" [3] (p. 19). To think that the superheroes will never die of natural causes, can fly, or have supernatural powers is more conceivable because these characteristics are 
intuitive. Alberto Luque also affirms that this kind of visual narratives is perceived as realistic, given the fact that the objects, scenarios, and actions assume an organic consistency of the real, and the plot develops according to the human logic [15].

For instance, Spiderman, having been bitten by a spider, has spiderlike abilities. However, if the superheroes were charged with too many disconnected abilities, they would not be that easily recallable because their superpowers would not make any sense to the established logic. Superman is a good example: "Although Superman can fly, shoots lasers from his eyes, and even travels back in time, Siegel's and Shuster's original had only advanced muscles" [3] (p. 21). The increase of his superpowers has therefore been a gradual process which has permitted the audience to accept him as a superhuman who fights against gradually more sophisticated and more dangerous menaces. From the narrative point of view, it is a necessary adjustment as the villains have been acquiring more strength and becoming more powerful.

In this sense, the archetype molds with society mirroring its needs and concerns, but according to Curtis, this reinforcement of society's moral values can be just one of the possibilities to exploit in the superhero genre. Another way could be that superheroes become "agents of social change that actively call for a break with the dominant and herald [ ... ] [8] (p. 2). As mentioned before, Superman fought against injustice and various menaces coming from the inside as well as outside of America, even from other alternative universes. He fought for social causes such as against racism or drug abuse, and he could become a weapon to address other topics in regard to stereotypes of ethnicity, sexuality, gender, or aging. Taking advantage of the power of the mythical value of a superhero, this genre could "open a path to social and political change" [8] (p. 2). However, since the origins of Superman, he has represented a rather conservative icon of the American way of life "defined around the four pillars of capitalism, patriarchy, heterosexuality and white supremacy [8] (p. 9). Although there have been efforts to break with this outdated representation which no longer reflects the mind-set of American society, these were not effective as to combat the stereotypes deeply embedded in society. That is also the case of the graphic novel Kingdom Come, which will be discussed hereunder. On the contrary, taking the symbolic meaning of what a superhero's costume represents, a couple of examples will be provided to demonstrate that superheroes can indeed challenge agism in an effective way.

\section{Image of Aging in Kingdom Come}

In regard to the evolution of Superman as the most famous superhero of our times, it is not until 1996 that DC comic industry allows to break in the law of permanency and publishes an alternative four-issue miniseries Kingdom Come, written by Mark Waid and Alex Ross, which was later converted into a single volume graphic novel with the same title (2008), where the readership can find a Superman who grew old. Although it may seem like a giant leap in the genre, the book mainly reproduces several stereotypes rooted in American society. In the opening scene, an old man introduced as Wesley narrates a nightmare of Apocalypse to his friend who is a priest, and who is said that his nightmare is a product of his decreasing health and coming senility, a stereotype of old age associated with "dependence, decrepitude and death" [16] (p. 10). Moreover, Wesley is presented as an archetype of an old grump, yearning for old times where superheroes, the "costumed champions" [17] (p. 18), used to contribute to maintaining a peaceful life on Earth, and represented the old values which have been progressively forgotten. According to Ortega y Gasset [18], the olden times are yearned for when a society does not feel the plenitude of their present and when its deficiencies are perceived in comparison to classical times. Those were presented as broader, richer, and more perfect in detriment of the decadence of the present. Therefore, the comic highlights a popular belief that old people do not understand the world that surrounds them, which is another cliche to break.

In the same light, Superman is portrayed as a retired man living on a Midwestern farm. He is dressed in overalls, his hair is grey and long with sideburns, tight in a ponytail. 
His face is ridden by wrinkles on his forehead and brows. Superman in Kingdom Come is set apart from society, and prefers to be addressed by his original name from his planet Krypton, Kal. This last fact detaches him even more from the rest of humans, as he tries to suppress the humanlike part of his dual identity. This kind of crisis can be compared to the biased cultural image of the elderly, hidden from public view, involved in equally biased gendered activities.

The person behind Superman's retirement is one of the new breeds of heroes called Magog who was chosen by the people as a new younger version of a superhero: "Vox populi, man. Out with the old, in with the new. Brighter, faster, meaner ... next year's model. That's what the hungry crowd always wants" [17] (p. 96). Similarly, Batman also makes Superman see that they are both offstage, in a similar light as the episode "The Home for Old Super-Heroes!" in Action Comics \#386: "Once ordinary folks decided you and I were too gentle and old-fashioned to face the challenges of the 21st century. They wanted their 'heroes' stronger and ruthless" [17] (p. 73). He states that they were set apart since they are obsolete and of no particular use. Again, the authors reproduce the stereotype related to the old age and uselessness.

Another stereotype present in the comic is the dichotomy of young and old generation. The present is ruled by the young ones, who are the children and grandchildren of the old superheroes. However, they neither maintain nor believe in the old values of their parents. Instead, they instill violence as they fight for the sake of fighting. Whereas the old generation represents the values of truth and justice, the young one is military-based and does not care about humans. While the young ones are strong but with their morals besmirched, the old ones have aged faces and bodies, but they are noble and wise, with a strong sense of justice and welfare, which posits an interesting dichotomy of wisdom and frailty in regard to old age. The values of strength, power, and youth are promoted in this literary manifestation of popular culture as a product of contemporary consumer culture [16], in detriment of values linked to the natural process of aging. However, as the present society led by young generation seems in crisis, Waid and Ross challenge the typecast dichotomy by calling the old generation back on stage.

In need of allies, Superman visits a disco where young people usually gather. In that kind of place, a person with his old-fashioned haircut is visibly seen as an intruder and thus is quickly challenged by one of the youngsters: "Ain't it past your bedtime, grampa? What does the 'S' stand for? Senile?" [17] (p. 86). Out of his comfort zone and in minority, Superman is mocked and not taken seriously. His polite ways are no longer valid in the present corrupted world. However, the manner to impose their ways through violence is something that Superman refuses to accept, for it disagrees with his personal ethics. Throughout history, Superman has encountered many kinds of enemies: Nazis, Russians, or nuclear threats, but as an old man, he is unable to adjust to a society which no longer shares the same values, and which he does not understand. In the "Apocrypha" of Kingdom Come, Waid explains the following:

Superman is the one who has changed the least over the years. Unfortunately, the world has changed outrageously. Shunned by a public that has instead grown enamoured with the more savage, bloodthirsty, chrome-suited avengers of tomorrow, Superman is completely mystified as to what his role in society should be. He's never lost his sense of decency, but he has no idea how to apply it in a world so seemingly disinterested in decency [17] (p. 216).

Superman is not used to being challenged by anybody and especially not by the young ones. The ones who rebel against him are imprisoned by force in a sort of gulag and are full of anger now. One typecast youngster with a tattooed face, piercings and leather necklace with spikes representing the new generation shouts: "'Man of tomorrow', my ass. Try 'man of the nineteen-fifties!' Times change ... But he still expects everyone to live up to some cobwebbed code! [ . . . ] I'm sick of this medieval thinking!" [17] (p. 117). It is evident how an important generational clash is taking form in this story. Indeed, the opinion of the new generation is related to the negative image of the elderly whose ideas are obsolete 
and no longer valid for younger generations. The young generation in Kingdom Come pays tribute to the cult of youth representing vigor and power, and, on the other hand, questions the wisdom of the old ones gathered throughout life experience, which is relegated to the fringe.

In Kingdom Come, Superman is portrayed as an aging man in existential crisis, quite humanlike, despite the effort of getting rid of all his human nature. Nor does he find his place in the modern society, and experiences "an internal struggle over who [he is] and what [his] role is in a changed world" [12] (p. 144). He was already retired from public life, working on his farm, but had to come back because his moral code, and of course his archetypical nature, obliged him to serve the community once more. The authors put into his hands a very difficult decision of whether to save humanity from a nuclear catastrophe, or sacrifice others of his kind. Nevertheless, the real challenge for Superman resides in finding a way to adjust to a new world and, moreover, learn to forgive himself for past failures. Like our aging population, he experiences a psychological challenge related to growing old which is managing ego preoccupation of what has been done wrong and right, what could have been done or what should have been done [13].

If the authors wanted to denounce the predominantly negative image of aging in popular culture, they failed; for they reproduce many other stereotypes in characters' depiction, both physical as well as psychological. Regarding physical features of the characters, they all have grey hair and wrinkles. Even though their strength seems to be kept, it is because of their supernatural origins; however, Batman, who is originally a human, wears a kind of exoskeleton which highlights his physical fragility. In addition, although Wonder Woman does not age and cannot die, she is depicted with grey hair too. Batman, having discovered she was pregnant, makes the following sexist comment: "For an ageless amazon of perfect physique, you've put on a pound or two" [17] (p. 210).

From the psychological point of view, the aged superheroes depicted in Kingdom Come stereotypically embody the tradition and old values, clashing with the young generation of superhumans, portrayed typecast, having bald heads, dyed hair, piercings and tattoos. Both generations do not move from the hackneyed cultural portrayals of the young-old dichotomy and therefore do not challenge any cultural stereotype set in American society. The aged Superman is a result and a biased social portrayal of the elderly in greying America [12].

\section{The Symbolic Dimension of a Superhero's Costume in American Society}

Far from comic art, the superhero's costume has become something more than just a dress code; it has acquired a symbolic meaning which has progressively detached from the body that wears it. Therefore, it does not belong exclusively to the superhero, but it is shared by society as a symbol of empowerment. Consequently, it is broadly used for different purposes in our society, beyond its literary meaning, which will be discussed hereunder.

The first case of using a superhero's garment as a symbol of empowerment is a campaign against prostate cancer in aging men, started in 2002 and presented to the public in 2007 to raise awareness about this health problem. This campaign uses an aging superhero, a common manwith prostate problems called Prostate Man (Due to a reserved copyright, see the illustrations of the Prostate Man in the article by Lyzun, K. and A. McMullen [19]):

'Take It Like a Man', encouraging men age 50 and over to be aware of their risk for prostate cancer, recognize the signs and symptoms of prostate cancer, and talk with their healthcare provider about prostate cancer testing. This paper focuses on the most recent campaign iteration: 'Take It Like a Man - Prostate Man'. Created in 2007, this multimedia campaign features a middle-aged superhero, Prostate Man, who comes to terms with the reality of ageing. An interactive online comic book, also available in hard copy, follows Prostate Man in his quest for knowledge about the risk factors, signs and symptoms of prostate cancer, 
providing actionable advice for men to lower their risk for prostate cancer [19] (p. 7).

This humor-based Canadian campaign achieved immediate success and developed different variations on the theme for six years after its release. Prostate Man "uses bold, classic comic book imagery and humor to garner attention and motivate discussion among men aged fifty and over on this important topic in men's health" [19] (p. 8). It is therefore no surprise that this way of raising awareness about the prostate cancer in North-western Ontario was more effective than taken as 'serious or threatening'. It proved that men appeared to respond better to humor-based health promotion because the target audience was, in fact, able to "self-identify with the campaign's imagery and the campaign's ability to maintain a consistent, distinct identity to ensure audience recollection and stimulate conversation" [19] (p.13).

According to Scott McCloud, the successful reception of this character is given to the universality of cartoon imagery: "The more cartoony a face is, for instance, the more people it could be said to describe" [20] (p. 31). He makes a distinction between a realistic portrait in which one can see a face of another person, and a cartoony face, where one tends to see themselves. "I believe this is the primary cause of our childhood fascination with cartoons [ ... ] the cartoon is a vacuum into which our identity and awareness are pulled" [20] (p. 36). In this sense, the Prostate Man, a middle-aged man (but "young at heart") in yellow tights, "sporting the uniform, but [is] overweight and living a more sedentary lifestyle" and, after some years, "begins to follow his own advice, loses weight, and feels like a superhero for taking responsibility for his health" [19] (pp. 13-15), becomes a perfect mirror for the target audience who is, in broad terms, like him.

The second case of superhero imagery beyond literature comes from an artistic project of a contemporary artist Jason Bard Yarmosky called "Wintered Fields" (2016), in which he portrays his grandmother, suffering from Alzheimer, in a Wonder Woman costume against wintry landscape (Due to a reserved copyright, see the examples of Yarmosky's exposition on his personal webpage [21]). On his personal webpage he posted an article published by The Wall Street Journal where he states: "My grandmother was a wonder woman to me ... I wanted to contrast her age and predicament with this symbolic costume to show both the heroism and vulnerability of the human condition" [22]. Though not exactly the same as the previous case, each use of superhero imagery focuses on one particular characteristic of a superhero; whereas in the first one it adopts the role to encourage middle-aged men to undergo an important medical check to reduce prostate cancer, in the second example it works as a tribute to the artist's personal hero, his grandmother, and offers a frank portrayal of an aged body, pointing to the uniqueness of our elderly. In both cases, it breaks the biased imagery of a young and vigorous body of an archetypical superhero.

\section{Conclusions}

The phenomenon of aging has acquired varying connotations across historical periods and cultures. In fact, social constructionists assert that the perception of growing old is an individual experience which is influenced by society and culture; therefore, it is not pre-given [16]. Indeed, age is a social construct [23] and the general view of the process of aging is a result of how it is portrayed in different kinds of media.

It has been shown that the superhero comic genre reproduces, seen from the perspective of literary and cultural gerontology, many stereotypes in regard to old age. A priori, the superhero must conserve his youth because his image is connected to strength and strength to his ability to fight evil, the main mission of all kinds of superheroes. The discussed alternative graphic novel Kingdom Come (2008) introduces an aged Superman, but beholds one main perspective: in the contemporary world, there is scarcely a place for old heroes, which also echoes infrequent presence of the elderly in the media [16]. The merit of this oeuvre could possibly lie in shedding light on a social problem of intergenerational clash in America, as well as on the place and agency of the growing population of the older generation. The old Superman from Kingdom Come is no longer needed in the present, 
a fact that reverberates in the disengagement of the elderly from the society after their retirement. Once Superman is retired, he takes his experience, wisdom and values with himself. From the socio-environmental perspective, the elderly should become active agents within society "as guides, role models, and mentors to younger generations" [12] (p. 152), a role that Wonder Woman adopts in Kingdom Come at the very end of the story.

In this sense, the graphic novel provides visibility for an evident social need for change in how the older part of the population is seen and depicted in literature and culture. In the case of the superhero genre, it has been demonstrated that although there are cases of superheroes who aged, these representations remain stereotypical and therefore do not challenge agism grounded in society's mind-set. Fortunately, there are some alternative graphic narratives that use the symbolism of a superhero costume to pay tribute to the elderly. For instance, the Spanish author David Robles in his graphic novel Recuerdos de mi Primer Domingo depicts his grandfather, taller than skyscrapers, with an undulating cravat instead of the superhero's cape, seen from a low perspective of an admiring child. The illustration is accompanied by the following lines: "My personal superhero always appeared at work with a costume, but this one was made up of a jacket and a dazzling shield ... " [24] (n.p.). In this graphic novel, the grandfather is an active member of society, described with many facets that make him a unique individual and a round character. Even though his hair is white, it is symbolically compared to a snowed peak of a high mountain, which also connotes the protagonist's exceptionality. In my opinion, this kind of graphic narratives stand as successful alternatives to a senior typecast superhero, for they are portrayed as distinctive individuals with unique personality traits, as well as set in realistic, non-stereotypical settings, engaged in variety of behaviors. Moreover, they interact with younger generations and these relationships are depicted as mutually beneficial and satisfying. Therefore, the symbolic meaning of the superhero's costume as a symbol of empowerment has the ability to break social and cultural stereotypes related to aging. We do not possess the Holy Grail to avoid biological aging, but we do have interesting tools which can provide a better and more realistic portrayal of what it means to be old in our contemporary society.

Funding: This research received no external funding.

Institutional Review Board Statement: Not applicable.

Informed Consent Statement: Not applicable.

Data Availability Statement: Not applicable.

Conflicts of Interest: The author declares no conflict of interest.

\section{References}

1. Klotz, K. The Golden Bough: Literature and the Idea of Immortality. J. Aesthetic Educ. 1979, 13, 29-37. [CrossRef]

2. Rohde, E. Psyche: The Cult of Souls and Belief in Immortality among the Ancient Greeks; Ares: Chicago, IL, USA, 1987.

3. Gavaler, C. Superhero Comics; Bloomsbury Academic: London, UK, 2018.

4. Campbell, J. The Hero with a Thousand Faces; Princeton University Press: Princeton, NJ, USA, 2004.

5. García, S. Novela Gráfica; Astiberri: Bilbao, Spain, 2010.

6. Hanlon, H.; Farnsworth, J.; Murray, J. Ageing in American Comic Strips: 1972-1992. Ageing Soc. 1997, 17, 293-304. [CrossRef]

7. Brooker, M.K. (Ed.) Comics through Time: A History of Icons, Idols, and Ideas; Greenwood: Santa Barbara, CA, USA; Denver, CO, USA; Oxford, UK, 2014; Volume 1, pp. 1800-1960.

8. Curtis, N. Superheroes and the Mythic Imagination: Order, Agency and Politics. J. Graph. Nov. Comics 2019. [CrossRef]

9. Goud, M. Dissecting the Man of Steel: The Evolution of Superman as a Reflection of American Society. Bachelor's Thesis, Bellarmine University, Louisville, KY, USA, 2020.

10. Cover Browser. 2006. Available online: http://www.coverbrowser.com/covers/action-comics (accessed on 20 February 2021).

11. Brooker, M.K. (Ed.) Comics through Time: A History of Icons, Idols, and Ideas; Greenwood: Santa Barbara, CA, USA; Denver, CO, USA; Oxford, UK, 2014; Volume 2, pp. 1960-1980.

12. Miczo, N. Aging Superheroes: Retirement and Return in Kingdom Come and Old Man Logan. In Aging Heroes: Growing Old in Popular Culture; Jones, N., Batchelor, B., Eds.; Rowman \& Littlefield: Lanham, MD, USA, 2015; pp. $143-155$. 
13. Solomon, K.; Szwabo, P.A. The Work-Oriented Culture: Success and Power in Elderly Men. In Older Men's Lives; Thompson, E.H., Jr., Ed.; Sage: Thousand Oaks, CA, USA, 1994; pp. 42-64.

14. Eco, U. The Myth of Superman. Diacritics 1972, 2, 14-22. Available online: http://comicsstudies.pbworks.com/w/file/fetch/50 572544/eco-superman.pdf (accessed on 23 February 2021). [CrossRef]

15. Luque, A. El Doble Sentido (Antitético) del Esoterismo y su Efecto en el Cine Primitivo. Un Art d'Espectres: Màgia i Esoterisme en el Cinema dels Pimers Temps. Fundació Museu del Cinema-Col-lecció Tomàs Mallol/Ajuntament Girona 2010, 1, 63-83.

16. Blaikie, A. Ageing \& Popular Culture; Cambridge UP: Cambridge, UK, 1999.

17. Waid, M.; Ross, A. Kingdom Come; DC Comics: New York, NY, USA, 2008.

18. Ortega y Gasset, J. The Revolt of the Mases; Norton, Cop.: New York, NY, USA. Available online: https://wwnorton.com/books / 9780393310955 (accessed on 1 January 2021).

19. Lyzun, K.; McMullen, A. ‘Prostate Man': The Ageing Superhero: A Unique Approach to Encouraging Prostate Health Awareness among Men over 50. J. Commun. Healthc. 2009, 2, 7-19. [CrossRef]

20. McCloud, S. Understanding Comics: The Invisible Art; Kitchen Sink Press: New York, NY, USA, 1993.

21. Yarmosky, J.B. Selected Works. 2017. Available online: http:/ /www.jasonyarmosky.com/2017 (accessed on 19 February 2021).

22. Yarmosky, J.B. News. 2019. Available online: http:/ / www.jasonyarmosky.com/news (accessed on 19 February 2021).

23. Gullette, M. Aged by Culture; The University of Chicago Press: Chicago, IL, USA; London, UK, 2004.

24. Robles, D. Recuerdos de Mi Primer Domingo; Señales de Humo: Spain, 2009. 